\begin{tabular}{lcc}
\hline & ANNALES \\
& UNIVERSITATIS MARIAE CURIE-SKLODOWSKA \\
LULLIN - POLONIA & \\
LECTIO N & 2016 \\
\hline
\end{tabular}

Lindy McAllister

University of Sydney

lindy.mcallister@sydney.edu.au

\title{
The Role of Competency-Based Occupational Standards in Speech Pathology Education and Governance in Australia
}

\author{
Rola standardów zawodowych opartych o wymogi \\ kompetencyjne w edukacji i praktyce logopedycznej w Australii
}

Summary: Integrated competency-based occupational standards allow detailed description of the knowledge, skills and attributes which in combination portray competent professional practice. Competency-based occupational standards have been in place within the speech pathology profession in Australia since 1994, and are used for a range of educational and assessment purposes, including assessing eligibility for membership of the Speech Pathology Association of Australia. This paper describes the reasons for and process of development of the standards, the framework for the standards, and how they are used for curriculum development and assessment. The paper also describes the use of CBOS in the development of a validated tool for the assessment of clinical performance.

Keywords: competency-based education; speech pathology; CBOS; Australia; $\mathrm{COMPASS}^{\oplus}$

\section{INTRODUCTION}

Competency-based occupational standards (CBOS) have been in place within the speech pathology (SP) profession in Australia for more than 20 years. They were first published in 1994 by the professional association - Speech Pathology 
Australia - and revised in 2001 and 2011. The standards are used to determine eligibility for membership of Speech Pathology Australia of Australian graduates, overseas trained SPs seeking to practice in Australia, and Australian SPs seeking to return to clinical practice after a break of more than 5 years. Australia has a dual entry pathway into the health professions: students can complete a Bachelor degree or a two year graduate entry masters degree for students with prior relevant degrees such as psychology or linguistics. There are 14 four year Bachelor degrees and nine 2 masters degrees offered in 15 universities. All programs must be accredited by Speech Pathology Australia. Entry level competency-based occupational standards are used to frame the degree curricula and also to assess graduates of these degrees. This paper describes the reasons for and process of development of the standards, the framework for the standards, and how they are used for curriculum development and assessment. The paper also describes the use of CBOS in the development of a validated tool for the assessment of clinical performance.

\section{COMPETENCY-BASED OCCUPATIONAL STANDARDS}

There is much contention around competency frameworks for the professions. Approaches to describing competency range from atomistic or reductionist approaches which provide detailed, unwieldy lists of discrete skills, to holistic approaches which see knowledge, skills, attributes and values of the professional integrated and demonstrated in competent practice ${ }^{1}$. Integrated approaches recognise professional practice as more than the simple sum of its parts ${ }^{2}$ and avoid the "slice and dice" approaches to curriculum documentation and assessment ${ }^{3}$ that yields lists of small isolated skills, which alone may be mastered and assessed as discrete technical skills but not be integrated into competence 'practice'. The profession of speech pathology in Australia choose to adopt the integrated approach to competency, as reflected in the Competency-Based Occupational Standards for Speech Pathologists - Entry level ${ }^{4}$. The CPLOL NetQues project ${ }^{5}$

1 A. Gonczi, A guide to the development of competency standards for the professions, Canberra: National Office for Overseas Skills Recognition, 1992.

2 Ibidem.

3 M.A. Albanese, G. Mejicano, W.M. Anderson, L. Gruppen, Building a competency-based curriculum: The agony and the ecstasy, "Advances in Health Sciences Education" 2010, No. 15, pp. 439-454.

4 Competency-based Occupational Standards for Speech Pathologists (Revised), Melbourne, Australia: Speech Pathology Association of Australia, 2011.

5 Comitée Permanent de Liaison des Orthophonistes-Logopèdes de l'Union Européenne (CPLOL), NetQues project report: speech and language therapy education in Europe: United in 
also used an integrated competency approach to the development of its tuning standards for SP education in Europe.

\section{THE DEVELOPMENT OF COMPETENCY-BASED OCCUPATIONAL STANDARDS FOR SPEECH PATHOLOGY IN AUSTRALIA}

The development of competency-based occupational standards for the professions began in Australia in the early 1990s in response to demands from the federal government for standards which would enhance portability of qualifications, enable a ladder of qualifications from 'assistant' level to fully qualified professional status, and enable valid and reliable assessment of overseas qualified professionals wishing to migrate to work in Australia. Speech Pathology Australia obtained federal government funding to run a national project with its members and stakeholders (e.g., registration boards, employers of SPs [health departments, disability agencies, education departments, academics, students]), to develop the CBOS. A nationwide consultation project using an action research approach was used to engage members, academics, service managers and other stakeholder organisations around the country in working parties and focus groups, to describe and reiteratively define entry-level competent practice for new graduates in all workplace settings. Through cycles of consultations CBOS was refined into 7 Units and associated Elements of practice. Guided by principles for competency-based assessment outlined by Gonczi, Hager and Athanasou ${ }^{6}$, strategies for assessment of the CBOS in entry-level students and new graduates were developed and piloted with students, academic clinical educators and student placement supervisors, as described by Dawson ${ }^{7}$. Data from these pilots were further used to refine CBOS, which was then published (Speech Pathology Association of Australia, 1994). CBOS was subsequently revised in 2001 and $2011^{8}$ to both reflect and drive the broadening scope of practice of speech pathology in Australia.

diversity, CPLOL, 2013, www.netques.eu/wp-content/uploads/2013/10/NetQues_Project_Report_SLT_Education_in_Europe_260913.pdf, accessed: 29 II 2016.

6 A. Gonczi, P. Hager, J. Athanasou, The development of competency-based assessment strategies for the professions, National Office of Overseas Skills Recognition, Research Paper No. 8. Canberra: Australian Government Printing Service, 1993.

7 S. Robertson, J. Rosenthal, V. Dawson, Using assessment to promote student learning, [in:] Facilitating Learning in Clinical Settings, ed. by L. McAllister, M. Lincoln, S. McLeod, D. Maloney, London: Nelson Thornes, 1997, pp. 154-184.

8 Competency-based Occupational Standards for Speech Pathologists, Melbourne Australia: Speech Pathology Association of Australia, 1994. 


\section{SCOPE OF SPEECH PATHOLOGY PRACTICE IN AUSTRALIA}

Before describing the CBOS, it is important that readers understand the range of practice, frameworks and principles for speech pathology practice in Australia. Speech Pathology Australia ${ }^{9}$ defines speech pathology practice as incorporating:

[...] any, or a combination, of these domains for communication and swallowing disorders across the lifespan:

- advocacy,

- clinical services,

- consultation,

- education,

- prevention,

- research.

Speech Pathology Australia ${ }^{10}$ defines the range of practice for entry level speech pathologists as follows:

Speech pathologists are professionals with expertise in communication and swallowing disorders. Communication refers to speech, verbal and nonverbal language, written language, voice and fluency. Swallowing refers to dysphagia, oral function and mealtime management.

An entry-level speech pathologist in Australia must be able to demonstrate competence in all units of $\mathrm{CBOS}$ in paediatric and adult speech pathology practice with both developmental and acquired disorders in the areas of:

- language,

- speech,

- swallowing,

- voice,

- fluency,

- multi-modal communication.

Four principles apply to the range of practice as listed in Table 1.

9 Competency-based Occupational Standards for Speech Pathologists (Revised), p. 3.

10 Ibidem, p. 7. 
Table 1. Principles of Practice for Entry level speech pathologists in Australia

\begin{tabular}{|l|}
\hline \multicolumn{1}{|c|}{ Principle 1} \\
\hline $\begin{array}{l}\text { In all work contexts and decision-making, the speech pathologist must consider the recom- } \\
\text { mended evidence base for the speech pathology practice }\end{array}$ \\
\hline \multicolumn{1}{c|}{ Principle 2} \\
\hline $\begin{array}{l}\text { Speech pathologists at entry-level are not required to demonstrate full competence in areas } \\
\text { of complex clinical practice }\end{array}$ \\
\hline \multicolumn{1}{c|}{ Principle 3} \\
\hline $\begin{array}{l}\text { There are a number of designated areas within the range of practice of speech pathology that } \\
\text { tialing in order for the speech pathologist to provide them }\end{array}$ \\
\hline \multicolumn{1}{c|}{ Principle 4} \\
\hline $\begin{array}{l}\text { Interprofessional practice is a critical component of competence for an entry-level speech } \\
\text { pathologist }\end{array}$ \\
\hline
\end{tabular}

Source: Competency-based Occupational Standards for Speech Pathologists (Revised), Melbourne, Australia: Speech Pathology Association of Australia, 2011, pp. 8-9.

Speech Pathology Australia (2011) further locates speech pathology practice in Australia within the framework of International Classification of Functioning, Disability and Health (ICF) ${ }^{11}$, and highlights the importance of evidence-based practice.

\section{DESCRIPTION OF COMPETENCY-BASED OCCUPATIONAL STANDARDS FOR SPEECH PATHOLOGY IN AUSTRALIA}

CBOS uses a holistic approach to competency which sees knowledge, skills, attributes and thinking as integrated and demonstrable in clinical performance. Competence is defined in seven broad Units of activity, as listed in Table 2.

Table 2. Units of Competence in CBOS

\begin{tabular}{|l|}
\hline Unit 1: Assessment \\
\hline Unit 2: Analysis and interpretation \\
\hline Unit 3: Planning evidence-based speech pathology practice \\
\hline Unit 4: Implementation of speech pathology practice \\
\hline Unit 5: Planning, providing and managing speech pathology services \\
\hline Unit 6: Professional and supervisory practice \\
\hline Unit 7: Lifelong learning and reflective practice \\
\hline
\end{tabular}

Source: own work.

11 International Classification of Functioning, Disability and Health (ICF), Geneva: WHO, 2001. 
The seven Units of competence, although defined through consultation just within the SP profession, are consistent with the Units of competence found across the health professions, as defined in a later national project ${ }^{12}$, further adding to the validity of the CBOS. In SP CBOS, these Units are then detailed within Elements - an example for Unit 3 appears in Table 3.

Table 3. Example of Elements within a Unit - Unit 3: Planning evidence-based SLP practices

Element 3.1. Use integrated and interpreted information (outlined in Unit 2) relevant to the communication and/or swallowing condition, and/or the service provider's policies and priorities to plan evidence-based speech pathology practice

Element 3.2. Seek additional information required to plan evidence-based speech pathology practice

Element 3.3. Discuss long-term outcomes and collaborate with the client and/or significant others to decide whether or not speech pathology strategies are suitable and/or required

Element 3.4. Establish goals for intervention in collaboration with the client and significant others

Element 3.5. Select an evidence-based speech pathology approach or intervention in collaboration with the client and significant others

Element 3.6. Define roles and responsibilities for the management of the client's swallowing and/or communication condition

Element 3.7. Document speech pathology intervention plans, goals and outcome measurement

Source: own work.

Table 4. An example of Elements, Performance Criteria and Cues in CBOS (2011) for Unit 1 Assessment

\begin{tabular}{|l|l|}
\hline \multirow{2}{*}{ Elements } & $\begin{array}{l}\text { The Elements provide key descriptions of the components of each Unit. They } \\
\text { detail specific activities to be demonstrated. }\end{array}$ \\
\hline $\begin{array}{l}\text { e.g., Unit 1 Assessment; Element 1.1. Investigate and document the client's com- } \\
\text { munication and/or swallowing condition and explore the primary concerns of } \\
\text { the client. }\end{array}$ \\
$\begin{array}{l}\text { Performance } \\
\text { Criteria }\end{array}$ & $\begin{array}{l}\text { The Performance Criteria are descriptions of speech pathology practice activi- } \\
\text { ties. The Performance Criteria provide detail about the level expected in order } \\
\text { to infer competency in the Element. } \\
\text { e.g., 3. Establish the impact of the communication and/or swallowing condition } \\
\text { in relation to the client and significant others. (Include components of the ICF ). }\end{array}$ \\
\hline
\end{tabular}

12 M. O'Keefe, A. Henderson, B. Jolly, L. McAllister, L. Remedios, R. Chick, Harmonising higher education and professional quality assurance processes for the assessment of learning outcomes in health, Final project report to the Australian Government Office for Learning and Teaching, 2013. 


\begin{tabular}{|l|l|}
\hline Cues & $\begin{array}{l}\text { The Cues illustrate the knowledge, actions, attitudes and contextual features } \\
\text { that impact on competency. The Cues provide practical examples of the applica- } \\
\text { tion of the Performance Criteria. The Cues given in the document are not to be } \\
\text { considered comprehensive for any one Element. } \\
\text { e.g., Interview processes: development of rapport, direct questioning, reflective } \\
\text { questioning. }\end{array}$ \\
\hline
\end{tabular}

Source: own work.

These Elements are further detailed in Performance Criteria and Cues which guide assessors making judgements about observed performance of students or graduate clinicians. An example of these are provided in Table 4 below which shows Performance Criteria and Cues for Unit 1 Assessment, and its first element regarding investigation and documentation of client conditions and concerns. For a full description of the Units, Elements, Performance Criteria and Cues please see Speech Pathology Australia (2011).

\section{USES OF COMPETENCY-BASED OCCUPATIONAL STANDARDS FOR SPEECH PATHOLOGY IN AUSTRALIA}

Competency-based Occupational Standards for Speech Pathologists were first introduced to Australian speech pathologists in 1994. Since then generations of SPs in Australia have been educated and assessed using the CBOS. Consequently, the standards are well understood and used in educational and practice settings, as well as in the professional association. The current speech pathology workforce in Australia is estimated to be around 8,500-9,000 ${ }^{13}$. Australia has only one association representing speech pathologists - Speech Pathology Australia. Although all speech pathologists working in Australia must be deemed 'eligible for membership' to be employed by employers, not all speech pathologists join the association. Private practitioners must be members for their patients to obtain health insurance rebates. Speech Pathology Australia uses the CBOS for a range of purposes, including those outlined in Table 5.

Speech Pathology Australia delegates assessment of competence of students completing degree programs in Australia to the universities but Speech Pathology Australia accredits all degree programs to ensure rigorous assessment of competence of their students by universities. All students, whether graduating from a bachelor or master degree in SP, must achieve competency across the

13 Understanding the landscape - a stimulus paper, Melbourne: The Speech Pathology Australia Association of Australia Ltd., 2016. 
range indicators listed earlier, for all 7 Units of Competence and the associated 37 Elements of Competence (as described earlier). Accreditation of speech pathology degrees in Australia is 'outputs' focused - that is, what matters is the output of rigorously assessed competence, not 'inputs' which specify hours required for different areas of study within the degree, or hours of clinical practice in each disorder area, an approach used in other countries.

Table 5. Applications of Competency-based Occupational Standards (Revised) (2011) by Speech Pathology Australia

\begin{tabular}{l}
$\begin{array}{l}\text { Inform candidates for entry to the profession (both Australian and overseas) of the standards } \\
\text { and range of competencies that they must achieve prior to recognition as a member of the } \\
\text { profession }\end{array}$ \\
\hline $\begin{array}{l}\text { Inform and guide the assessment and re-education of those wishing to re-enter the profession } \\
\text { (e.g., if not worked for > } 5 \text { years) }\end{array}$ \\
\hline Inform the profession of areas relevant for professional development \\
\hline $\begin{array}{l}\text { Inform the institutions (universities) responsible for the education of SLPs of the competency } \\
\text { demanded of entry-level speech pathologists in Australia }\end{array}$ \\
\hline $\begin{array}{l}\text { Inform entry-level speech pathologists and employers of the range and standard of independent } \\
\text { practice they can expect of an entry-level speech pathologist in Australia }\end{array}$ \\
\hline $\begin{array}{l}\text { Inform government and policy makers of the range and standard of practice of an entry-level } \\
\text { speech pathologist in Australia }\end{array}$ \\
\hline
\end{tabular}

Source: Competency-based Occupational Standards for Speech Pathologists (Revised), Melbourne, Australia: Speech Pathology Association of Australia, 2011 (italics added by the author).

This output focus allows universities to develop curricula which enable different pathways to the endpoint of competence, creating diverse and innovative approaches to speech pathology education in Australia. The key is endpoint, rigorous assessment which is assisted by the use of assessment mapping across curricula, and the use of Competency Assessment in Speech Pathology $\left(C^{2} \text { MPASS }{ }^{\circ}\right)^{14}$, a rigorous, validated and highly reliable tool used to assess the competence of speech pathology students in all degree programs in Australia and New Zealand, and increasingly internationally as well.

14 S. McAllister, M. Lincoln, A. Ferguson, L. McAllister, COMPASS ${ }^{\bullet}$ Competency Assessment in Speech Pathology, Melbourne, Australia: The Speech Pathology Association of Australia Ltd., 2006. 


\section{ASSESSING ACROSS THE RANGE OF COMPETENCIES IN AN ENTRY LEVEL SPEECH PATHOLOGY DEGREE}

To enable easy alignment with the program accreditation requirements of Speech Pathology Australia, Australian degree programs can structure their curricula so that all Units and Elements covering all range indicators are addressed both theoretically and practically at least once in the program ${ }^{15}$. Documentation for each subject can show which Units and Elements are covered and assessed for each Learning Outcome in the subject; for example, in a Child Language and Literacy subject, one learning outcome might be Identify assessment schema and management plan approaches for primary schoolchildren and for adolescents with suspected and/or diagnosed spoken/written language impairments. (Units1-4). This alignment then allows the creation of an assessment map which shows each Unit and Element, and where in each subject they are assessed, and how (e.g., exams, vivas, clinical assessments, portfolios, projects, simulation). Speech Pathology Australia expects to see a range of rigorous assessment types as well as direct observation of student competence in clinical settings. A reliance on written exams and assignments alone is not permitted. Assessment maps form part of the extensive documentation required for submission to Speech Pathology Australia's accreditation panels for consideration prior to site visits to the university undergoing accreditation, for exploration and confirmation of evidence provided. A portion of such an assessment map is shown in Table 6.

Table 6. An example of a portion of an assessment map against the CBOS (2011) required for speech pathology program accreditation in Australian universities

\begin{tabular}{|l|l|l|l|l|}
\hline Unit/Element & $\begin{array}{c}\text { Subject Child } \\
\text { Phonology }\end{array}$ & $\begin{array}{c}\text { Subject } \\
\text { Aphasia }\end{array}$ & Subject Motor Speech Disorders & \\
\cline { 1 - 4 } 1.1. & Assignment & Group Project & $\begin{array}{l}\text { Video made by student demon- } \\
\text { strating intervention techniques }\end{array}$ & $\begin{array}{l}\text { continue } \\
\text { for all sub- } \\
\text { jects in the } \\
\text { degree }\end{array}$ \\
\cline { 1 - 3 } 1.2. & Written exam & Case study & Viva & \\
\hline 3.1. & OSCE & Simulation lab & Written exam & \\
\hline Continue to 7.4. & & Portfolio & & \\
\hline
\end{tabular}

OSCE - Objective Structured Clinical Exam

Source: Competency-based Occupational Standards for Speech Pathologists (Revised), Melbourne, Australia: Speech Pathology Association of Australia, 2011.

15 A. Ferguson, M. Lincoln, L. McAllister, S. McAllister, COMPASS ${ }^{\oplus}$ directions: Leading the integration of a competency based assessment tool in speech pathology learning and teaching, Sydney: Australian Learning \& Teaching Council Ltd., an initiative of the Australian Government Department of Education, Employment and Workplace Relations, 2008. 


\section{ASSESSMENT OF STUDENTS' COMPETENCY ON PRACTICUM: COMPETENCY ASSESSMENT IN SPEECH PATHOLOGY COMPASS ${ }^{\circ}$}

Assessment of knowledge and skills in speech pathologists and students in a range of settings (e.g., simulation, exams, assignments, portfolios) is important but the real challenge is assessment of actual performance and demonstration of competency in the workplace ${ }^{16}$. This challenge has been met with the development of Competency Assessment in Speech Pathology $\left(\mathrm{COMPASS}^{\circ}\right)^{17}$. COMPASS ${ }^{\circ}$ addresses the need for fairness and authenticity and includes recognition of learning and development ${ }^{18}$.

COMPASS $^{\circ}$ was developed in a large scale national project between 2002 and 2004 with funding from the Australian Research Council, and Speech Pathology Australia as an industry partner. Most Australian universities offering speech pathology degrees were involved, along with hundreds of academics, clinical educators and students, who were involved in focus groups held at the start of the project to develop the structure and acceptability features of the tool. In addition to the seven Units and 37 Elements of CBOS, educators involved in the development phase of $\mathrm{COMPASS}^{\circ}$ suggested it was important to capture four generic competencies for learning:

- communication skills,

- clinical reasoning,

- professionalism,

- lifelong learning.

SPs around Australia later participated in pilots to validate and reliability test the tool. The sensitivity of COMPASS ${ }^{\circ}$ to levels of competence and changes in student performance over time was confirmed with complex statistical analyses including Rasch analysis ${ }^{19}$. The development of COMPASS ${ }^{\circ}$ has been documented previously ${ }^{20}$. $\mathrm{COMPASS}^{\circ}$ was later revised when $\mathrm{CBOS}$ was revised in 2011. An online portal for COMPASS ${ }^{\circ}$ was funded and is supported by Speech

16 V. Wass, C. van der Vleuten, J. Shatzer, R. Jones, Assessment of clinical competence, "The Lancet" 2001, Vol. 357, pp. 945-949.

17 S. McAllister, M. Lincoln, A. Ferguson, L. McAllister, COMPASS ...

18 S. McAllister, M. Lincoln, A. Ferguson, L. McAllister, Issues in developing valid assessments of speech pathology students' performance in the workplace, "International Journal of Language and Communication Disorders" 2010, Vol. 45 (1), pp. 1-14.

19 S. McAllister, Competency based assessment of speech pathology students' performance in the workplace, Unpublished PhD thesis, The University of Sydney, Australia, 2005.

20 See: S. McAllister, M. Lincoln, A. Ferguson, L. McAllister, A systematic program of research regarding the assessment of speech-language pathology competencies, "International Journal of Speech-Language Pathology" 2011, Vol. 13, pp. 469-479. 
Pathology Australia. COMPASS ${ }^{\odot}$ is used in every speech pathology degree course in Australia and New Zealand, and universities in South East Asia and the UK have expressed interest.

Based on observation of student performance during work with patients, $\mathrm{COMPASS}^{\circ}$ allows clinical educators/supervisors of students to make mid-placement and end-of-placement assessments of students' achievement of competence against the seven Units and 37 Elements of CBOS, and the four generic competencies for learning described earlier. $\mathrm{COMPASS}^{\circ}$ allows educators to indicate judgment of student performance on a visual analogue scale, anchored by novice performance at one end and entry level performance at the other. This allows the demonstration of development and growth in competence over time and series of placements undertaken by students. Judgments of performance are supported by detailed descriptors of what novice vs intermediate vs entry level performance on each Unit/Element would look like. There is a comprehensive training module for educators and students on how to use COMPASS ${ }^{\circ}$. Training has been shown to enhance reliability, although untrained educators familiar with CBOS have been shown to make valid and reliable judgments of performance $^{21}$. Students are encouraged to complete a self-assessment on COMPASS ${ }^{\circ}$ before attending meetings with their clinical educators/supervisors to discuss performance and agree on final marking of the scales. More detailed marking, at both Unit and Element level is undertaken at mid-placement for formative feedback purposes. Experienced and trained clinical educators can complete the detailed marking in about 50 minutes. A shorter summative assessment on Unit level only is typically undertaken for students at end of placement. A full assessment using Units and Elements may be undertaken at end of placement if a student is struggling to achieve competence and needs more direction and a learning plan to support future growth in competence. Students must demonstrate entry level competence before they can graduate. Universities must demonstrate to Speech Pathology Australia how all these processes are managed and quality assured as part of the accreditation of university degree courses.

Universities pay a small annual licence fee to Speech Pathology Australia to use the online $\mathrm{COMPASS}^{\circ}$ portal for marking. This expedites marking of students but also allows the generation of individual student reports, class reports, and university level reports. Any one university can only access its data, but can request a report which benchmarks their data against the aggregated and de-identified data from all other universities using COMPASS ${ }^{\circ}$. Individual universities can enter into formal agreements with other universities to share

21 S. Robertson, J. Rosenthal, V. Dawson, op. cit. 
data. This has allowed the development of large scale research projects on the development of competence in different types of students, the impact of placement types on competence development ${ }^{22}$ and the impact of different curricula models ${ }^{23}$ (e.g., traditional vs problem based learning; 4 year bachelor vs 2 year graduate entry masters) on the trajectories of competence development.

\section{CONCLUSION}

Competency-based occupational standards for entry level speech pathologists have been used in Australia for more than 20 years. These standards have been revised twice in that time to reflect and drive changes in the scope of practice. The standards are deeply embedded in the culture of speech pathology in Australia and are used for multiple purposes in education and governance of membership. This deep embedding and acceptance has allowed the standards to form the platform for a standardised tool $\left(\mathrm{COMPASS}^{\circ}\right)$ for the assessment of competence in students in the Australian and New Zealand degree courses. It has also enabled rich innovation and research in speech pathology education in these two countries. Other countries interested in the standards and in COM$\mathrm{PASS}^{\bullet}$ may need to consider the cultural appropriateness of these frameworks and how well they align with the scope of speech pathology practice before they embark on purchase and implementation for use in other countries.

\section{BIBLIOGRAPHY}

Albanese M.A., Mejicano G., Anderson W.M., Gruppen L., Building a competency-based curriculum: The agony and the ecstasy, "Advances in Health Sciences Education" 2010, No. 15, DOI: https://doi.org/10.1007/s10459-008-9118-2, pp. 439-454.

Comitée Permanent de Liaison des Orthophonistes-Logopèdes de l'Union Européenne (CPLOL), NetQues project report: speech and language therapy education in Europe: United in diversity, CPLOL, 2013, www.netques.eu/wp-content/uploads/2013/10/Net Ques_Project_Report_SLT_Education_in_Europe_260913.pdf, accessed: 29 II 2016.

22 L. Sheepway, M. Lincoln, S. McAllister, Impact of placement type on the development of clinical competency in speech-language pathology students, "International Journal of Language and Communication Disorders" 2014, Vol. 49 (2), pp. 189-203.

23 M. Lincoln, A. Ferguson, L. McAllister, S. McAllister, Benchmarking clinical learning in speech pathology to support assessment, discipline standards, teaching innovation and student learning, Sydney: Australian Learning \& Teaching Council Ltd., an initiative of the Australian Government Department of Education, Employment and Workplace Relations, 2008. 
Competency-based Occupational Standards for Speech Pathologists, Melbourne Australia: Speech Pathology Association of Australia, 1994.

Competency-based Occupational Standards for Speech Pathologists (Revised), Melbourne, Australia: Speech Pathology Association of Australia, 2011.

Ferguson A., Lincoln M., McAllister L., McAllister S., COMPASS ${ }^{\oplus}$ directions: Leading the integration of a competency based assessment tool in speech pathology learning and teaching, Sydney: Australian Learning \& Teaching Council Ltd., an initiative of the Australian Government Department of Education, Employment and Workplace Relations, 2008.

Gonczi A., A guide to the development of competency standards for the professions, Canberra: National Office for Overseas Skills Recognition, 1992.

Gonczi A., Hager P., Athanasou J., The development of competency-based assessment strategies for the professions, National Office of Overseas Skills Recognition, Research Paper No. 8. Canberra: Australian Government Printing Service, 1993.

International Classification of Functioning, Disability and Health (ICF), Geneva: WHO, 2001.

Lincoln M., Ferguson A., McAllister L., McAllister S., Benchmarking clinical learning in speech pathology to support assessment, discipline standards, teaching innovation and student learning, Sydney: Australian Learning \& Teaching Council Ltd., an initiative of the Australian Government Department of Education, Employment and Workplace Relations, 2008.

McAllister S., Competency based assessment of speech pathology students' performance in the workplace, Unpublished PhD thesis, The University of Sydney, Australia, 2005.

McAllister S., Lincoln M., Ferguson A., McAllister L., A systematic program of research regarding the assessment of speech-language pathology competencies, "International Journal of Speech-Language Pathology" 2011, Vol. 13,

DOI: https://doi.org/10.3109/17549507.2011.580782, pp. 469-479.

McAllister S., Lincoln M., Ferguson A., McAllister L., COMPASS ${ }^{\circ}$ Competency Assessment in Speech Pathology, Melbourne, Australia: The Speech Pathology Association of Australia Ltd., 2006.

McAllister S., Lincoln M., Ferguson A., McAllister L., Issues in developing valid assessments of speech pathology students' performance in the workplace, "International Journal of Language and Communication Disorders" 2010, Vol. 45 (1),

DOI: https://doi.org/10.3109/13682820902745461, pp. 1-14.

O’Keefe M., Henderson A., Jolly B., McAllister L., Remedios L., Chick R., Harmonising higher education and professional quality assurance processes for the assessment of learning outcomes in health, Final project report to the Australian Government Office for Learning and Teaching, 2013.

Robertson S., Rosenthal J., Dawson V., Using assessment to promote student learning, [in:] Facilitating Learning in Clinical Settings, ed. by L. McAllister, M. Lincoln, S. McLeod, D. Maloney, London: Nelson Thornes, 1997, pp. 154-184.

Sheepway L., Lincoln M., McAllister S., Impact of placement type on the development of clinical competency in speech-language pathology students, "International Journal of Language and Communication Disorders" 2014, Vol. 49 (2),

DOI: https://doi.org/10.1111/1460-6984.12059, pp. 189-203. 
Understanding the landscape - a stimulus paper, Melbourne: The Speech Pathology Australia Association of Australia Ltd., 2016.

Wass V., Vleuten C. van der, Shatzer J., Jones R., Assessment of clinical competence, "The Lancet" 2001, Vol. 357, DOI: https://doi.org/10.1016/S0140-6736(00)04221-5, pp. 945-949.

Streszczenie: Zintegrowane standardy zawodowe, oparte o wymogi kompetencyjne (CBOS), umożliwiają szczegółowy opis niezbędnej wiedzy, umiejętności i cech, które w połączeniu tworzą właściwą praktykę zawodową. Standardy zawodowe oparte o wymogi kompetencyjne zostały wprowadzone w zawodzie logopedy w Australii od 1994 roku i są wykorzystywane do różnych celów edukacyjnych oraz oceny, w tym oceny kwalifikacji niezbędnych do członkostwa w Stowarzyszeniu Patologii Mowy Australii. Artykuł opisuje przyczyny i proces rozwoju standardów, ramy standardów i to, jak są one wykorzystywane do tworzenia programu nauczania i oceny. Omówiono również zastosowanie CBOS-u w przygotowaniu rzetelnego, zalegalizowanego narzędzia do oceny wyników praktyki klinicznej.

Słowa kluczowe: edukacja oparta o wymogi kompetencyjne; logopedia; standardy zawodowe oparte o wymogi kompetencyjne; Australia; COMPASS ${ }^{\odot}$ 